\title{
PUTTING INTO CIRCULATION OR DRIVING AN UNLICENSED MOTOR VEHICLE PURSUANT TO THE NEW ROMANIAN PENAL CODE
}

\author{
Bela Zazula, Ph.D. candidate \\ University of the Academy of Science of Moldova
}

\begin{abstract}
The lawgiver of the new Penal Code proposed to charge into offences some deeds that endanger the public safety as social value protected by the penal norms and which, in their turn, include a series of values that might be harmed due to a breach of some rules established for the performance of certain activities, inhere for the social life, as well as those that set out, among others, the traffic safety on public roads.
\end{abstract}

Key words: public road, license, registration

\section{Introduction}

No matter the types and varieties of transport, ensuring the safety in transport is the thing that reflects the protection degree of both traffic participants and the entire society against transport accidents.

\section{Introductive considerations}

Traffic offences have as incrimination reason the need to protect the circulation safety on public roads. In doctrine ${ }^{1}$ is showed the fact that, although certain activities are characterized also by an intrinsic state of danger, we discuss of o permitted risk, as long as the activity it is talked about is performed within a legal framework.

In order to forbid at all such risk activities it would be susceptible to create greater inconvenient than allowing them in a strictly regulated framework. Therefore, in certain situations, the social utility of certain activities has the precedence at the expense of public safety, from an abstract point of view. That is how it is explained the intervention of the lawgiver by means of the penal law concerning the breach of the circulation rules on public roads. ${ }^{2}$

The incrimination of facts in this field through special laws, as it is the case of Germany and France by means of the Traffic Law, respectively of the Traffic Code, while other countries, such as Spain, regulate the offences against the traffic safety in Chapter IV of the Penal Code, and Republic of Moldova dedicated Chapter XII of the Penal Code to the offences related to transportation.

The offences against the safety on public roads were provided in our country in the previous regulation, O.U.G. no. 195/2002. 
The New Penal Code included the offences against the safety of the traffic on public roads in Chapter II that constitutes part of Title VII, dedicated to offences against the public safety, according to Spanish regulation.

The settlement of the offence of putting into circulation or driving an unlicensed motor vehicle, through the provisions of section 334 of the New Penal Code has the correspondent in section 85 of O.U.G. no. 195/2002 regarding the traffic on public roads, republished ${ }^{3}$.

The deeds incriminated through the provisions of section 334 paragraphs (1), (2), (3) and (4) have an almost identical content with their previous regulation, with differences under the aspect of the sanctioning regime. Considering the content, the only difference meant to clarify better the incrimination conditions, refers to the request that the motor vehicle or tram should not be licensed or registered pursuant to the law.

Considering the more favorable penal law, as it is provided, alternatively, the possibility of sanctioning by fine the deeds provided by section 334 paragraphs (1), (2) and (4), the New Penal Code represents the most favorable law, considering putting into circulation or driving a unlicensed motor vehicle ${ }^{4}$.

Also in the case of section 344 of the Penal Code, respectively considering putting into circulation or driving an unlicensed motor vehicle, it can be talked about protecting the safety of the traffic on public roads. This is because it is desired the state to have a record of the motor vehicles in order to know the real situation of the vehicle fleet, the licensing and registration being preceded by a series of checking, such as the origin of the good and the technical condition.

These checking underline the fact that the lawgiver followed to sanction the persons that put into circulation or drive motor vehicles that have not been checked pursuant to the above mentioned aspects.

The social value that is protected is represented by the traffic's safety on the public roads.

\section{Pre-existing conditions}

\section{A. The object of the offence}

a) Special juridical object

The special juridical object is represented by the social relationships that constitute and develop related to ensuring the traffic's safety on the public roads. In order to realize this purpose it is necessary the authorities to know the identification elements of all motor vehicle for which the law provided the licensing conditions 5 . The provisions of this article have as purpose ensuring a fluent and safe development of the circulation on the public roads, as well as the protection of life, bodily integrity and health of all the participants in traffic or found within the area of the public road. 


\section{b) Material object}

The analyzed offence has as material object the unlicensed or unregistered motor vehicle pursuant to the law.

According to another opinion ${ }^{6}$ this offence has no material object as the unlicensed motor vehicle, unregistered motor vehicle or with a false license number is not injured or affected in any way by the effectuation of the material element.

It can exist a material object, exceptionally, in case the license or registration numbers are falsified from a material point of view ${ }^{7}$.

\section{B. The subjects of the offence}

a) The active subject can be any person, and the penal participation is possible under all forms (co-author, instigation and complicity), but the co-authoring can be realized only by means of putting into circulation of a motor vehicle, not in the case of driving a motor vehicle on the public roads.

Concerning the action of driving, this can be committed only in the form of authoring. The argument is that the notion of driving involves the possibility of the agent to conduct the motor vehicle pursuant to his/her will, no matter the way in which it was actuated. In other words, the author is the one that drives the motor vehicle by auctioning the steering wheel.

In the situation in which the two modalities - putting into circulation and driving are performed directly by the same person, with the same occasion, it shall exist only one offence, as the alternative modalities of the material elements become simple deeds that integrate in a single action ${ }^{8}$.

In case of the hypothesis the motor vehicle belongs to a driving school, having two sets of pedals, the instructor shall not be considered an author, as the instructed one is the person that conducts the motor vehicle by means of the steering wheel. The action of the instructor of auctioning the pedals represents only a form of material complicity, as essential is the control of the motor vehicle's direction".

Regarding the juridical persons, considering the specific of the offences, these cannot have, in principle, the quality of active subject of this offence.

Though, in the modality of putting into circulation, the juridical person shall be responsible as author of the discussed offence. So, a juridical person that is in charge with selling the motor vehicles is putting these into circulation, knowing the fact that these motor vehicles are not licensed or registered.

b) The main passive subject is the state in his quality of guarantor for ensuring the safety of the circulation on the public roads.

\section{Conditions of place and time}

For the offence to exist the law does not provide special time conditions. Thou it is essential that the unlicensed motor vehicle to be put into circulation on public roads, by public road meaning any mean of terrestrial communication, except railway, specially arranged for pedestrian or motor vehicle traffic, opened to public 
circulation. The roads that are closed to public circulation are signalized with visible signs at entry.

Private utility roads are not public roads. Pursuant to section 3 letter b) of O.U.G. no. $43 / 1997$, private utility roads are the one designated to satisfy the proper road transport requests in economic activities, sylvan roads, petroleum roads, mining roads, agricultural, energetic, industrial and also precincts access roads and those inside the precincts, as well as those for site's organization and are managed by physical or juridical persons that have these roads in ownership or administration.

\section{Constituent content}

\section{A. The objective side}

a) The material element of the offence provided by section 344 paragraphs (1) consists of putting into circulation or driving on public roads a motor vehicle or a tram that is unlicensed or unregistered. Pursuant to incrimination norms the offence can be committed only by putting into circulation a motor vehicle or only by driving this motor vehicle on public roads.

Pursuant to O.U.H. no. 195/2002, a motor vehicle is described as being any vehicle equipped, by manufacturing, with a propulsion engine, with the purpose of road movement. Mopeds, trolleybuses and tractors are considered motor vehicles. The vehicles that use rails, named trams, tractors used exclusively for agricultural and sylvan exploitation, as well as the vehicles designated to perform services or works, named self-propelled machines that use only occasionally the public roads, are not considered motor vehicles.

The expression "putting into circulation" is hereby used by the lawgiver with the meaning of "disposition" or "assent" given by the person that owns or administrates an unlicensed vehicle, for that vehicle to be put into road traffic. Such disposition or task has significance - from the existence of the offence point of view - only when it is followed by its effective driving on public roads ${ }^{10}$.

For the offence to exist it is necessary that the unlicensed motor vehicle to be provided with a mechanical propulsion mean, that moves by its own means and that circulates on the public roads ${ }^{11}$. Under this aspect, in judiciary practice it has been decided that the defendant's deed of being at the steering wheel of a drawn motor vehicle, under the conditions in which this car had no functioning engine, does not meet the constituent elements of this offence, as the movement of the car on public roads had been performed as a result of the drawing by another motor vehicle.

The offences provided and sanctioned by section 344 of the Penal Code injure the social relationships regarding the record of the motor vehicle that travel on the public roads. By committing this offence it is disregarded the right of the police or, as the case might be, of other state organs that hold competences on keeping the 
record of the motor vehicles and trailers - of asking the holders of motor vehicles and trailers not to modify the licensing number, as well as the correlative obligation of travelling on the public roads only with the real licensing number.

The inquisition has to establish, on one hand, if the motor vehicle held a false licensing number and, on the other hand, if the accomplisher committed at least one of the illicit activities alternatively incriminated.

In order to travel on the public roads, the vehicles, except for those pulled or pushed by hand and bicycles have to be licensed or registered, as the case might be, and to hold plates with the licensing or registration number, having the form, dimension and content provided by current standards.

By "false licensing number" it has to be understood not only the number, entirely imaginary, placed on the motor vehicle by its owner, but also the number that corresponds to a previous licensing and that had no validity at that date, the motor vehicle being erased from the records of the competent organs.

The licensing or registration represents the administrative operation by which it is certified that a vehicle can circulate on the public roads. The proof of licensing or registration certification is the assigned registration or licensing certificate. Pursuant to the law, the licensing can be permanent or temporary. Permanent licensing or registration represents the operation by which it is granting a licensing or registration certificate and licensing or registration number for an undetermined period. Only licensing can be temporary. Temporary licensing represents the operation by which it is granted the licensing certificate and licensing number for a determined period.

A motor vehicle is unlicensed or unregistered when it has never been recorded in the records of the competent organs, even when it had been recorded before, but at the moment of committing the deed it had already been erased. Temporarily numbers are not licensing numbers, as their assigning it done based to a temporary authorization for circulation ${ }^{12}$.

It is forbidden to put into circulation a vehicle, licensed or registered, that has not mounted plates with the licensing or registration number assigned by the competent authority or if these are not in accordance with the current standards, as well as in the case the licensing or registration certificate is retained and the replacing proof is issued without circulation right or the validity term expired.

The material elements of the offence provided by section 344 paragraph (2) consist of putting into circulation or driving on public roads a motor vehicle or a tram having a false licensing or registration number.

By "false licensing number" it has to be understood not only the number, entirely imaginary, placed on the motor vehicle by its owner, but also the number that corresponds to a previous licensing and that had no validity at that date, the motor vehicle being erased from the records of the competent organs ${ }^{13}$. 
According to another theory, by false licensing or registration number has to be understood any type of non-concordance of this with the true resulted from the official documents, including loss of validity of an authentic number ${ }^{14}$.

The material element of the offence provided by section 344 paragraph (3) is represented by the hauling of an unlicensed or unregistered trailer or with a false licensing or registration number. The trailer is a vehicle without engine designated to be hauled by a motor vehicle or a tractor. The trailers are of two types: easy and semi-trailers. An easy trailer is the trailer of which the maximum permissible weight does not exceed $750 \mathrm{~kg}$ and the semi-trailer is the trailer of which the maximum permissible weight is partly taken over by a motor vehicle or a tractor.

Finally, the material element of the offence provided by section 344 paragraph (4) consists of driving on the public roads a motor vehicle or hauling a trailer of which plates with the licensing or registration number have been withdrawn or of a vehicle licensed in another state that has no circulation right in Romania. The withdrawal of the plates with the licensing or registration number is a technical administrative measure disposed by the traffic police, consisting in taking down the plates off the vehicle and their keeping at the office of the traffic police until the ceasing of the causes that lead to that measure.

The motor vehicles and trailer licensed in other countries, held by persons that have the registered office or residence in Romania, can be driven on the public roads for a period of no more than 90 days since their entry in the country, if they are insured for civil responsibility causes following the prejudice produced by motor vehicle accidents.

b) The immediate sequel consists of jeopardizing the safety of the circulation on public roads.

c) The causality relevance consists of committing the offence

\section{B. The subjective side}

\section{a) The subjective element}

The offences provided by section 344 of the Penal Code are committed only with intention, which can be direct or indirect.

There exists direct intention when the motor vehicle's driver foresees - as inevitable - the result of his/her deed and, implicitly, follows its producing, by committing that deed.

There exists indirect intention when the subject foresees - possible - the result and although he/she does not follow it, he/her accepts its producing. Committing the deed by negligence or without fault does not constitute an offence.

b) Reason and purpose

For the existence of the offence there is no interest for the reason or purpose of committing the deed. 


\section{Forms. Modalities. Sanctions.}

\section{A) Forms}

a) Attempt.

The offence is not susceptible in the form of the attempt. The preparatory deeds are not punished.

b) The consumption of the offence

The offence shall be considered consummated the moment the vehicle submitted to licensing or registration pursuant to the law is put into circulation or driven on the public roads.

\section{B. Modalities (Means)}

a) Normative modalities - section 344 provides in fact four distinct offences.

b) Factual modalities - the offence can be committed by a multitude of factual modalities.

\section{Sanctions}

The offence provided by:

- paragraph (1) is punished with prison from 1 to 3 years or by fine;

- paragraph (2) is punished with prison from 1 to 5 years or by fine;

- paragraph (3) is punished with prison from 3 months to 2 years or by fine;

- paragraph (4) is punished with prison from 6 months to 2 years or by fine;

\section{Procedural aspects}

The penal action shall be started ex officio. The penal prosecution shall not be performed obligatory by the prosecutor, this having only the obligation to rule and control directly the activity of penal prosecution performed by judiciary police. The competence in the first court belongs to the court house, pursuant to section 35 paragraph (1) letter a) of the Penal Procedure Code.

\section{Conclusions}

By defining safety as a state of order, equilibrium and social, economic and political stability needed for the society to exist, for the order to be maintained, it is found this cannot be ensured correspondingly except to when there exist some predominant conditions of proliferation of a lack of safety condition in all transport types, including the road one.

\section{Notes}

${ }^{1}$ Florin Streteanu, Penal Law Treaty. General Part, volume I, C.H. Beck Publishing House, Bucharest, 2008, p. 421

${ }^{2}$ Sergiu Bogdan, Doris Alina Serban, The New Penal Code. Special Part. Analysis, Explanations, Comments, Universul Juridic Publishing House, Bucharest, 2014, p. 585 
${ }^{3}$ Official Gazette no. 670 from $3^{\text {rd }}$ August 2006

${ }^{4}$ Tudorel Toader and collab., The New Penal Code. Comments on Sections, Hamangiu Publishing House, Bucharest, 2014, p. 526

${ }^{5}$ Alexandru Ionas, Alexandru Florin Magureanu, Cristina Dinu, Penal Law. Special Part, Universul Juridic Publishing House, Bucharest, 2015, p. 498

${ }^{6}$ Vasile Dobrinoiu and collab., The New Penal Code Comented. Special Part, Universul Juridic Publishing House, Bucharest, 2014, p. 703

${ }^{7}$ Mihai Adrian Hotca and collab., Offences Provided in Special Laws. Comments and Explanations, Edition 3, C.H. Beck Publishing House, Bucharest, 2013, p. 303 ${ }^{8}$ M. A. Hotca, op. cit., p. 303

${ }^{9}$ S. Bogdan, D. A. Serban. G. Zlati, op. cit., p. 586-587

${ }^{10}$ Alexandru Boroi, Penal Law. Special Part, Ch. Beck Publishing House, Bucharest, 2011, p. 498

${ }^{11}$ Vasile Pavaleanu, Special Penal Law, Universul Juridic Publishing House, Bucharest, 2014, p. 453

${ }^{12}$ Petre Dungan, The Analysis of the Offences' Content Against the Circulation on the Public Roads by Means of the New Penal Code (I), The Law, no. 2/2011, p. 49

${ }^{13}$ A. Boroi, op. cit., p. 498

${ }^{14}$ M.A. Hotca, op. cit., p. 307

\section{Bibliography}

1. F. Streteanu, Penal Law Treaty. General Part, volume I, C.H. Beck Publishing House, Bucharest, 2008

2. S. Bogdan, D.A. Serban, The New Penal Code. Special Part. Analysis, Explanations, Comments, Universul Juridic Publishing House, Bucharest, 2014

3. T. Toader and collab., The New Penal Code. Comments on Sections, Hamangiu Publishing House, Bucharest, 2014

4. A. Ionas, A.F. Magureanu, C. Dinu, Penal Law. Special Part, Universul Juridic Publishing House, Bucharest, 2015

5. V. Dobrinoiu and collab., The New Penal Code Comented. Special Part, Universul Juridic Publishing House, Bucharest, 2014

6. M.A. Hotca and collab., Offences Provided in Special Laws. Comments and Explanations, Edition 3, C.H. Beck Publishing House, Bucharest, 2013

7. A. Boroi, Penal Law. Special Part, Ch. Beck Publishing House, Bucharest, 2011

8. V. Pavaleanu, Special Penal Law, Universul Juridic Publishing House, Bucharest, 2014

9. Dungan, The Analysis of the Offences' Content Against the Circulation on the Public Roads by Means of the New Penal Code (I), The Law, no. 2/2011 